\title{
Heparin inhibits the inflammation and proliferation of human rheumatoid arthritis fibroblast-like synoviocytes through the NF-kB pathway
}

\author{
LI QI, XIAOLI ZHANG and XIAOFEI WANG \\ Department of Rheumatology and Immunology, Shengjing Hospital of China Medical University, \\ Shenyang, Liaoning 110022, P.R. China
}

Received August 6, 2015; Accepted July 22, 2016

DOI: $10.3892 / \mathrm{mmr} .2016 .5719$

\begin{abstract}
Fibroblast-like synoviocytes (FLSs) of rheumatoid arthritis (RA) lead to cartilage destruction, and the activation of NF- $\mathrm{KB}$ is important in the proliferation of FLSs. Heparin is a glycosaminoglycan, which is widely used as an anticoagulant. In the present study, the effect of heparin on the tumor necrosis factor (TNF)- $\alpha$ induced proliferation of FLSs was investigated. Western blot and polymerase chain reaction analyses were used to assess the expression levels of cytokines. The results revealed that TNF- $\alpha$ induced the expression of interleukin (IL)-6, IL-8, TNF- $\alpha$ and cyclin D1. Heparin inhibited the growth rate of the FLSs induced by TNF- $\alpha$. Heparin also decreased the TNF- $\alpha$-induced mRNA and protein expression levels of IL-6, IL-8, TNF- $\alpha$ and cyclin D1 in a dose-dependent manner. Immunofluorescence analysis showed that the expression of cytoplasmic TNF- $\alpha$ was significantly reduced by heparin treatment. Furthermore, the levels of p65 and inhibitor of nuclear factor (NF)- $\mathrm{kB}$ phosphorylation were inhibited by heparin treatment, suggesting that heparin induced the inhibition of NF- $\mathrm{kB}$. In conclusion, the results of the present study revealed that heparin inhibited the TNF- $\alpha$-induced proliferation, cytokine production, expression of cyclin D1 and activation of NF- $\mathrm{KB}$ signaling in FLSs, indicating the therapeutic potential of heparin in the treatment of RA.
\end{abstract}

\section{Introduction}

Rheumatoid arthritis (RA) is a common chronic inflammatory joint disease, which is characterized by inflammation, hyperplasia and destruction of joints $(1,2)$. Hypertrophic synovial

Correspondence to: Dr Xiaofei Wang, Department of Rheumatology and Immunology, Shengjing Hospital of China Medical University, 39 Hua Xiang Road, Tiexi, Shenyang, Liaoning 110022, P.R. China

E-mail: wangxiaofei_sj@yeah.net

Key words: heparin: nuclear factor- $\kappa \mathrm{B}$, fibroblast-like synoviocyte tissue in RA is composed of fibroblast-like synoviocytes (FLSs) and inflammatory cells, which secrete several inflammatory cytokines (3). Previous studies have demonstrated that tumor necrosis factor (TNF)- $\alpha$, which stimulates FLS proliferation, is critical in the pathogenesis of RA (4-6). TNF- $\alpha$ also activates a broad array of intracellular signaling mechanisms, including the nuclear factor (NF)- $\mathrm{kB}$ pathway (7).

$\mathrm{NF}-\kappa \mathrm{B}$ is important in inflammatory regulation, and several studies have suggested the role of NF- $\mathrm{\kappa B}$ activation during the development of RA (8-10). TNF- $\alpha$ stimulation activates NF- $\mathrm{KB}$ signaling in FLSs and leads to the production of cytokines, including TNF- $\alpha$, interleukin (IL) 6 and IL8 (11). In addition, there is a positive feedback loop between NF- $\kappa B$ and TNF- $\alpha$ (12), which is critical during the pathogenesis of RA. The inhibition of NF- $\mathrm{kB}$ signaling, particularly antibody-mediated inhibition of TNF- $\alpha$ function, has been found to significantly suppresses the progression of inflammation (13). These findings suggest that the inhibition of NF- $\mathrm{KB}$ is an important therapeutic approach for the treatment of RA (14-16).

Heparin is a sulfated glycosaminoglycan, which is widely applied as an injectable anticoagulant $(17,18)$. Although used principally in medicine for anticoagulation, other biological and physiological roles of heparin, and its underlying mechanisms remain to be fully elucidated. Previous reports suggest that heparin exerts inhibitory effects on NF-кB signaling in human endothelial cells, suggesting it may function as an inhibitor of FLS proliferation and lead to the progression of RA $(19,20)$. In the present study, the effects of heparin on the proliferation and activation of NF- $\mathrm{KB}$ in TNF- $\alpha$-stimulated FLSs were investigated. The present study aimed to determine the importance of heparin in FLSs, which may provide insights into the clinical impacts of this anticoagulant in patients with RA.

\section{Materials and methods}

Reagents and antibodies. Recombinant TNF- $\alpha$ was obtained from Cell Signaling Technology, Inc. (Danvers, MA, USA). RPMI-1640, fetal bovine serum (FBS), antibiotics, trypsin, phosphate-buffered saline (PBS) and other products for cell culture were purchased from Invitrogen; Thermo Fisher 
Scientific, Inc. (Waltham, MA, USA). Phosphorylated (p-) Akt,

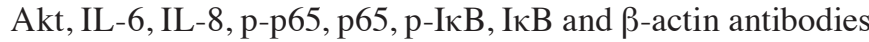
were purchased from Cell Signaling Technology, Inc. Heparin sodium for injection was purchased from Shanghai No. 1 Biochemistry \& Pharmaceutical Co., Ltd. (Shanghai, China).

Isolation and culture of FLSs. The present study was approved by the First Affiliated Hospital and Shengjing Hospital of China Medical University (Shenyang, China). Informed consent was obtained from all patients. The FLSs were isolated from primary synovial tissues obtained from three patients with RA who had undergone joint replacement surgery or synovectomy between 20013 and January 2014. The synovial tissue was sectioned and digested with $0.25 \%$ trypsin to isolate the synoviocytes, which were cultured in $5 \% \mathrm{CO}_{2}$ at $37^{\circ} \mathrm{C}$. Following overnight culture, the non-adherent cells were removed, and the adherent cells were cultivated in RPMI-1640 supplemented with $10 \%$ FBS. The FLSs were passaged following $0.25 \%$ trypsin treatment. FLSs in passages 3-8 were used in subsequent experiments. The cells were observed using a light microscope and were morphologically homogeneous and exhibited a typical bipolar configuration.

Treatment of the cells with TNF- $\alpha$ and heparin. FLS cells were cultured in plates. When $80 \%$ confluence was achieved, cells were treated with $10 \mathrm{ng} / \mathrm{ml} \mathrm{TNF}-\alpha$ alone and TNF- $\alpha(10 \mathrm{ng} / \mathrm{ml})$ with different concentrations of heparin $(0,0.1,1$ and $5 \mathrm{U} / \mathrm{ml})$ for 24,48 and $72 \mathrm{~h}$.

MTT assay. The cells were plated in 96-well plates $(\sim 3,000$ cells per well) and cultured for 5 days. MTT solution (20 $\mu \mathrm{l}$ of $5 \mathrm{mg} / \mathrm{ml}$ MTT) was added to each well. Following incubation for $4 \mathrm{~h}$ at $37^{\circ} \mathrm{C}$, the medium was removed and the remaining MTT formazan was dissolved in $150 \mu \mathrm{l}$ DMSO. The absorbance of the solution was measured at $490 \mathrm{~nm}$ using an absorbance microplate reader.

Reverse transcription-quantitative polymerase chain reaction $(R T-q P C R)$ analysis. Total RNA was extracted from fresh tissue samples and cells with TRIzol reagent (Thermo Fisher Scientific, Inc.) according to the manufacturer's protocol. Total RNA was reversed to cDNA using PrimeScript RT Master Mix (Takara,Biotechnology Co.,Ltd.,Dalian,China).A total $10 \mu \mathrm{l}$ of reverse-transcription reaction solution was prepared using $2 \mu \mathrm{l}$ of 5X RT Master Mix and 500 ng RNA. Reverse-transcription reaction was performed by incubating the samples at $37^{\circ} \mathrm{C}$ for $15 \mathrm{~min}$ and then $85^{\circ} \mathrm{C}$ for $5 \mathrm{sec} . \mathrm{qPCR}$ was performed as follows using $9 \mu \mathrm{l}$ water, $1 \mu \mathrm{l}$ cDNA and $10 \mu \mathrm{l}$ SYBR Green master mix (Thermo Fisher Scientific, Inc.): $50^{\circ} \mathrm{C}$ for $2 \mathrm{~min}, 95^{\circ} \mathrm{C}$ for $10 \mathrm{~min}, 40$ cycles of $95^{\circ} \mathrm{C}$ for $15 \mathrm{sec}, 60^{\circ} \mathrm{C}$ for $60 \mathrm{sec}$. The RT-qPCR analysis was performed using a 7900HT Real-Time PCR system (Thermo Fisher Scientific, Inc.). $\beta$-actin was used as the reference gene. The relative expression levels of target genes were calculated as $\Delta \mathrm{Cq}=\mathrm{Cq}$ gene $-\mathrm{Cq}$ reference, and the fold change in target gene expression was calculated using the $2^{-\Delta \Delta \mathrm{Cq}}$ method (21). Experiments were repeated in triplicate. The primer sequences were as followers: TNF- $\alpha$, forward 5'-TGACTGTCGCCCGCAGTACG-3' and reverse 5'-CGG CAATTTAGTGACACGCG-3'; IL-6, forward 5'-ACCGTC ATCATGTCTGACCA-3' and reverse 5'-TGGAACACCCTG
TCTTTGAC-3'; IL-8, forward 5'-ACCGTCATCATGTCT GACCA-3' and reverse 5'-TGGAACACCCTGTCTTTGAC-3'; cyclin D1, forward 5'-GCTGGAGGTCTGCGAGGA-3' and reverse 5'-ACAGGAAGCGGTCCAGGTAGT-3'; $\beta$-actin, forward 5'-ATAGCACAGCCTGGATAGCAACGTAC-3' and reverse 5'-CACCTTCTACAATGAGCTGCGTGTG-3'.

Western blot analysis. Total proteins from the cells were extracted in lysis buffer and quantified using the Bradford method. A $30 \mathrm{mg}$ quantity of protein was separated by $10 \%$ SDS-PAGE. The samples were then transferred onto PVDF membranes (EMD Millipore, Billerica, MA, USA) and incubated overnight at $4{ }^{\circ} \mathrm{C}$ with primary antibodies against TNF- $\alpha$ (cat. no. 6945), IL-6 (cat. no. 12153) and cyclin D1 (cat. no. 2978; 1:900; all from Cell Signaling Technology, Inc., Danvers, MA, USA), IL-8 (cat. no. 7922; 1:500; Santa Cruz Biotechnology, Inc., Dallas, TX, USA) and actin (cat. no. 47778; 1:1,000; Santa Cruz Biotechnology, Inc.). This was followed by incubation with peroxidase-coupled anti-mouse or rabbit IgG antibody (1:1,000 dilution; Cell Signaling Technology, Inc.) at $37^{\circ} \mathrm{C}$ for $2 \mathrm{~h}$. Target proteins on the PVDF membrane were visualized using a Pierce ECL kit (Pierce, Rockford, IL, USA) and images were captured using a DNR Bio-Imaging system (DNR Bio-Imaging systems, Ltd., Jerusalem, Israel).

Immunofluorescence staining. Following washing with cold PBS, The FLSs were fixed with $4 \%$ formaldehyde in PBS for $10 \mathrm{~min}$. Subsequently, the cells were treated with $0.25 \%$ Triton X-100 (Sigma-Aldrich, St. Louis, MO, USA). The cells were then washed three times in PBS for 5 min each, followed by blocking for $10 \mathrm{~min}$ with $5 \%$ goat serum. The cells were then incubated with TNF- $\alpha$ primary antibody diluted in PBS with 3\% bovine serum albumin (1:500; Beyotime Institute of Biotechnology, Shanghai, China) overnight at $4^{\circ} \mathrm{C}$. The cells were then incubated with AlexaFluro 488 conjugated-goat anti-rabbit IgG for $2 \mathrm{~h}$ at room temperature. Immunofluorescence was visualized under a fluorescence microscope (Olympus Corporation, Tokyo, Japan).

Statistical analysis. Data are expressed as the mean \pm standard deviation. Statistical analysis was performed using SPSS 12.0 software (SPSS, Inc., Chicago, IL, USA). The results were compared using one-way analysis of variance with post-hoc tests. $\mathrm{P}<0.05$ was considered to indicate a statistically significant difference.

\section{Results}

Effect of heparin on the proliferation rate of FLSs. The effect of heparin on FLS growth rate was determined using an MTT assay. The cells were treated with TNF- $\alpha(10 \mathrm{ng} / \mathrm{ml})$ and different concentrations of heparin $(0,0.1,1$ and $5 \mathrm{U} / \mathrm{ml})$ for 24, 48 and $72 \mathrm{~h}$. As shown in Fig. 1, heparin treatment, particularly at concentrations of 1 and $5 \mathrm{U} / \mathrm{ml}$, significantly inhibited the proliferation rate of the FLSs induced by TNF- $\alpha$ treatment $(\mathrm{P}<0.05 ; 5 \mathrm{U} / \mathrm{ml}$ group at $24 \mathrm{~h} ; 1$ and $5 \mathrm{U} / \mathrm{ml}$ groups at $48 \mathrm{~h} ; 1$ and $5 \mathrm{U} / \mathrm{ml}$ groups at $72 \mathrm{~h}$ ).

Effect of heparin on TNF- $\alpha$-induced mRNA expression levels of the TNF- $\alpha, I L-6, I L-8$ and cyclin DI NF- $\kappa B$ target genes in 


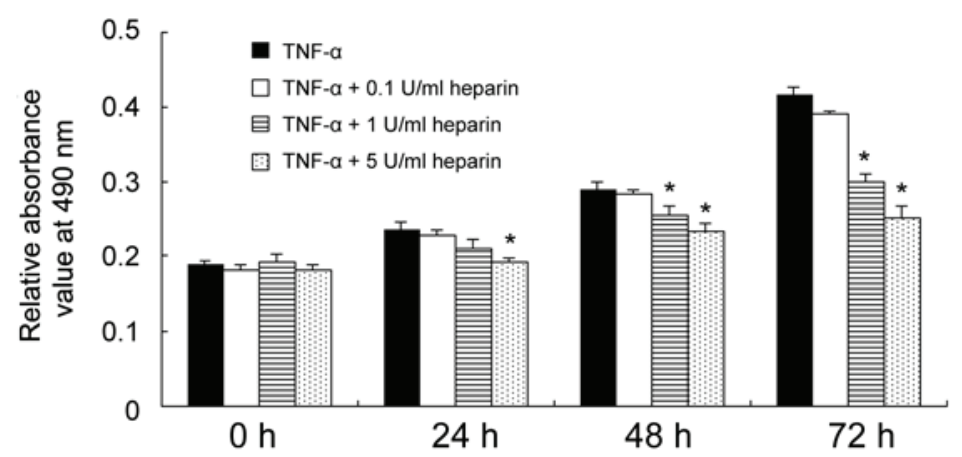

Figure 1. Effect of heparin on the proliferation rate of FLSs. FLSs were treated with TNF- $\alpha$ and different concentration of heparin $(0,0.1,1$ and 5 U/ml) for 24, 48 and $72 \mathrm{~h}$. Heparin significantly inhibited the proliferation rate of the FLSs. "P<0.05 vs. TNF- $\alpha$ group. FLS, fibroblast-like synoviocyte; TNF- $\alpha$, tumor necrosis factor- $\alpha$.

A
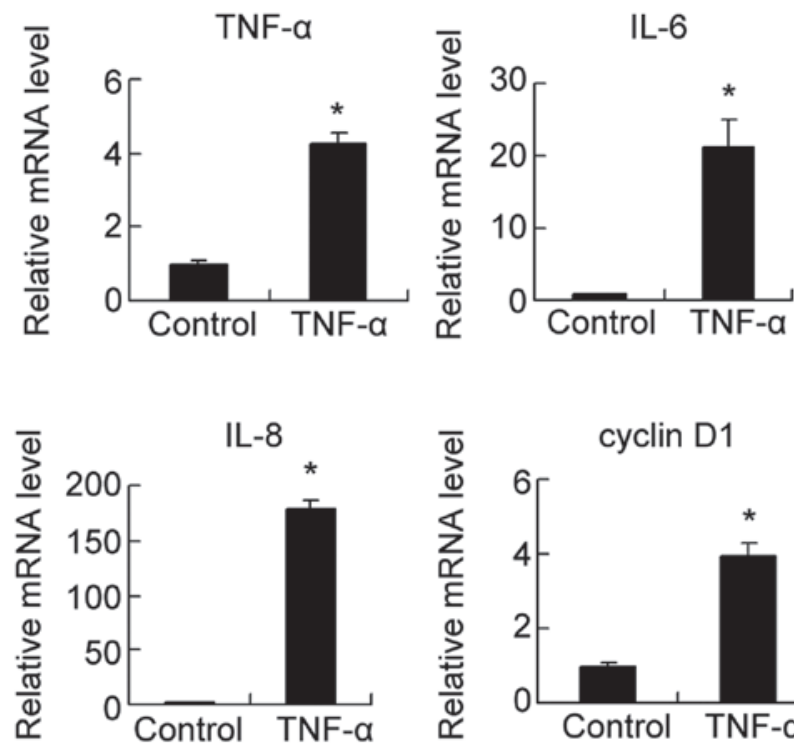

B
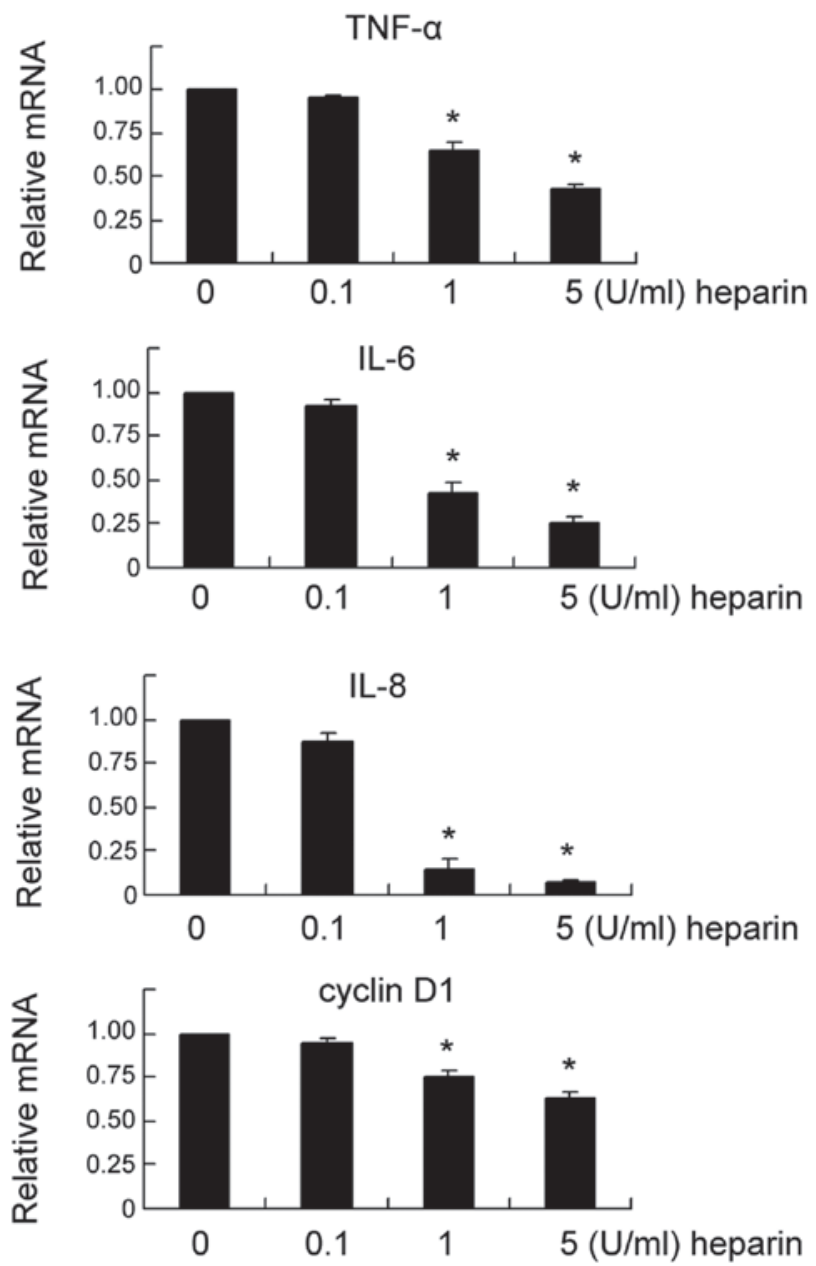

Figure 2. Effect of heparin on the NF-кB target genes TNF- $\alpha$, IL-6, IL-8 and cyclin D1. (A) Treatment with TNF- $\alpha$ (10 ng/ml) for $24 \mathrm{~h}$ upregulated the mRNA expression levels of TNF- $\alpha$, IL-6, IL-8 and cyclin D1. (B) Heparin treatment decreased the mRNA levels of TNF- $\alpha$, IL-6, IL-8 and cyclin D1 in a dose-dependent manner. " $\mathrm{P}<0.05$ vs. TNF- $\alpha$ group. FLS, fibroblast-like synoviocyte; TNF- $\alpha$, tumor necrosis factor- $\alpha$; IL, interleukin.

FLSs. TNF- $\alpha$ is a downstream target of the NF- $\mathrm{kB}$ pathway, which also activates NF- $\kappa \mathrm{B}$ signaling. Previous studies have reported a positive feedback loop between TNF- $\alpha$ and NF- $\mathrm{kB}$ signaling (22-24). Therefore, the present study examined the effect of TNF- $\alpha$ on the expression of NF- $\kappa$ B target genes using RT-qPCR. As shown in Fig. 2A, 24 h of TNF- $\alpha$ treatment
$(10 \mathrm{ng} / \mathrm{ml})$ significantly upregulated the mRNA expression of the NF- $\kappa \mathrm{B}$ target genes, including TNF- $\alpha$, IL-6, IL-8 and cyclin D1, compared with the untreated control $(\mathrm{P}<0.05)$.

Subsequently, the role of heparin on the mRNA expression levels of the TNF- $\alpha$, IL-6, IL- 8 and cyclin D1 NF- $\kappa$ B target genes was investigated. The FLSs were treated with $10 \mathrm{ng} / \mathrm{ml}$ 


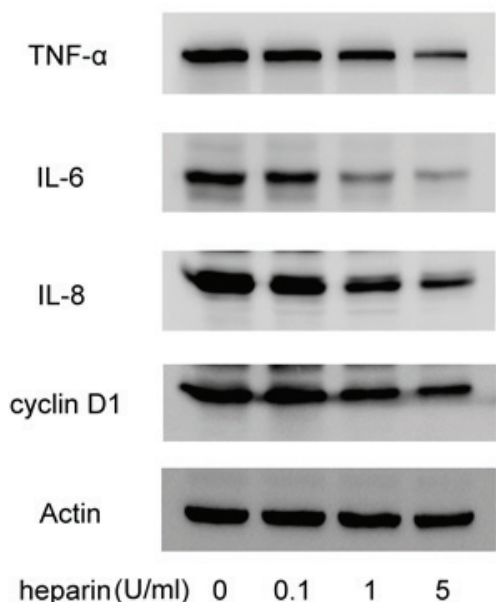

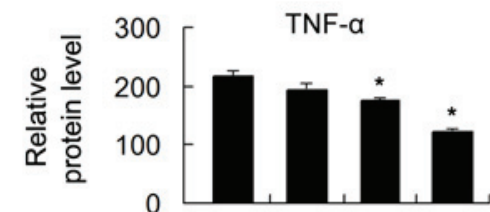

$\operatorname{heparin}(\mathrm{U} / \mathrm{ml}) \quad 0 \quad 0.1 \quad 1 \quad 5$

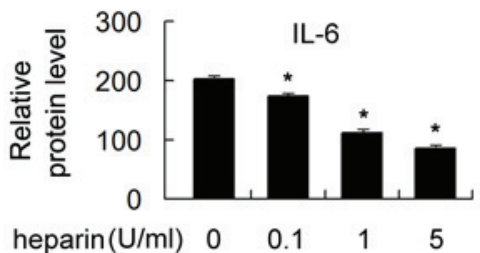

$\operatorname{heparin}(\mathrm{U} / \mathrm{ml}) \quad 0 \quad 0.1 \quad 1 \quad 5$

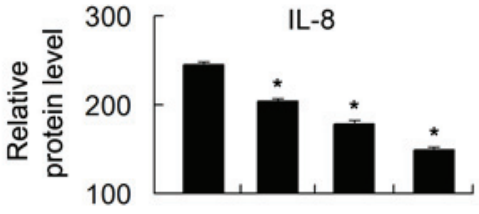

heparin $(\mathrm{U} / \mathrm{ml}) \quad 0 \quad 0.1 \quad 1 \quad 5$

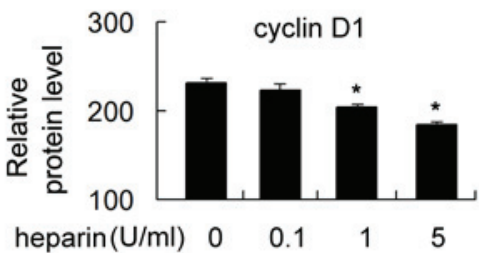

Figure 3. Effect of heparin on the protein expression levels of TNF- $\alpha$, IL-6, IL-8 and cyclin D1. Heparin treatment decreased the protein levels of TNF- $\alpha$, IL-6, IL- 8 and cyclin D1 in the FLSs in a dose-dependent manner. "P<0.05 vs. 0 U/ml heparin group. FLS, fibroblast-like synoviocyte; TNF- $\alpha$, tumor necrosis factor- $\alpha$; IL, interleukin.

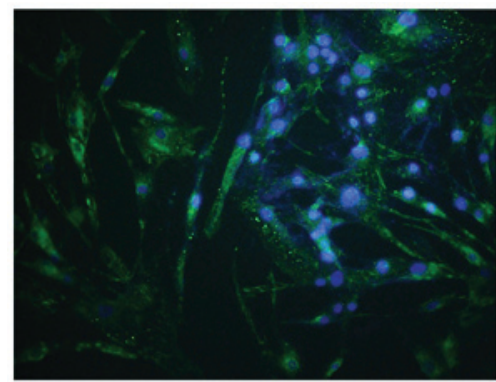

$0 \mathrm{U} / \mathrm{ml}$ heparin

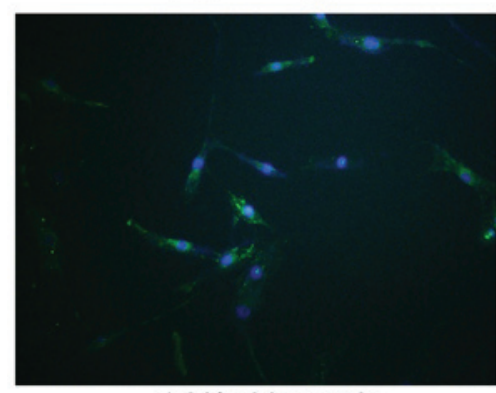

$1 \mathrm{U} / \mathrm{ml}$ heparin

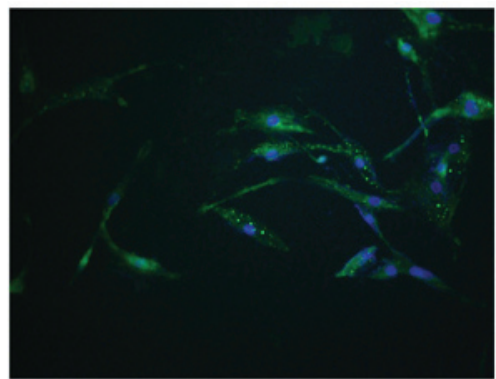

$0.1 \mathrm{U} / \mathrm{ml}$ heparin

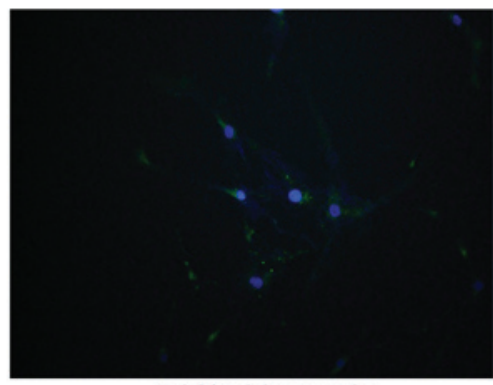

$5 \mathrm{U} / \mathrm{ml}$ heparin

Figure 4. Immunofluorescence staining of TNF- $\alpha$ in fibroblast-like synoviocytes treated with heparin. Immunofluorescence showed that heparin treatment induced a dose-dependent decrease in the cellular protein expression of TNF- $\alpha$. Magnification, $x 400$. TNF- $\alpha$, tumor necrosis factor- $\alpha$.

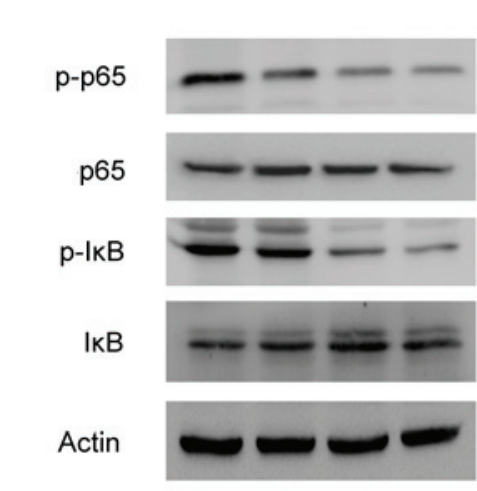

heparin $(\mathrm{U} / \mathrm{ml}) \quad 0 \quad 0.1 \quad 1 \quad 5$
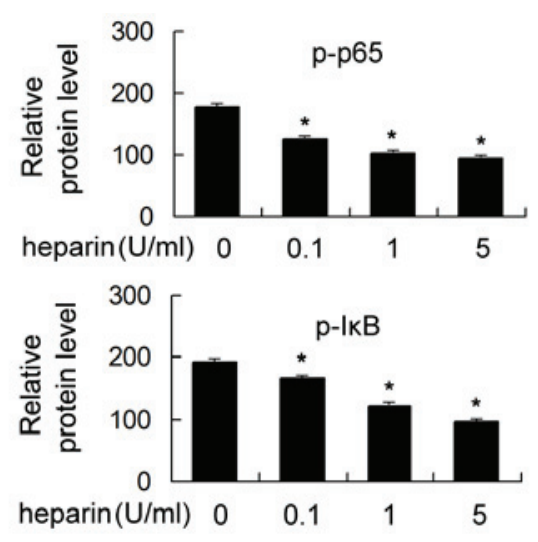

Figure 5. Effect of heparin on nuclear factor- $\kappa \mathrm{B}$ signaling activation. Western blot analysis showed that the levels of p-p65 and p-I $\kappa \mathrm{B}$ decreased following heparin treatment in a dose-dependent manner. ${ }^{*} \mathrm{P}<0.05$ vs. $0 \mathrm{U} / \mathrm{ml}$ heparin group. p-phosphorylated; I $\kappa \mathrm{B}$, inhibitor of nuclear factor- $\kappa \mathrm{B}$. 
of TNF- $\alpha$ for $24 \mathrm{~h}$, following which the FLSs were exposed to different concentrations of heparin $(0,0.1,1$ and $5 \mathrm{U} / \mathrm{ml})$. As shown in Fig. 2B, heparin treatment decreased the mRNA levels of TNF- $\alpha$, IL-6, IL-8 and cyclin D1 in a dose-dependent manner ( 1 and $5 \mathrm{U} / \mathrm{ml}$ groups; $\mathrm{P}<0.05$ ).

Effect of heparin on the protein expression levels of TNF- $\alpha$, $I L-6, I L-8$ and cyclin DI in FLSs. Western blot analysis was used to examine heparin-induced changes in the protein levels of TNF- $\alpha$, IL-6, IL-8 and cyclin D1. The FLSs were treated with $10 \mathrm{ng} / \mathrm{ml}$ of TNF- $\alpha$ for $24 \mathrm{~h}$, following which the FLSs were exposed to different concentrations of heparin $(0,0.1,1$ and $5 \mathrm{U} / \mathrm{ml})$ or another $24 \mathrm{~h}$. As shown in Fig. 3, heparin treatment significantly decreased the protein levels of TNF- $\alpha$, IL-6, IL-8 and cyclin D1 in a dose-dependent manner $(\mathrm{P}<0.05)$. In addition, immunofluorescence was used to examine protein expression and localization of TNF- $\alpha$ in the heparin-treated FLS. As shown in Fig. 4, TNF- $\alpha$ was located in the cytoplasm of the FLSs, and heparin treatment dose-dependently decreased the cellular protein expression of TNF- $\alpha$.

Effect of heparin on $N F-\kappa B$ activity. To investigate the mechanism by which heparin inhibits proinflammatory cytokines, the present study examined the effect of heparin on the phosphorylation of p65 and $\mathrm{I} \kappa \mathrm{B}$, which are key proteins of the $\mathrm{NF}-\kappa \mathrm{B}$ signaling pathway. As shown in Fig. 5, the levels of p-p65 and p-IкB were significantly reduced following heparin treatment in a dose-dependent manner, suggesting that heparin inhibited NF- $\kappa \mathrm{B}$ activity in the FLSs $(\mathrm{P}<0.05)$.

\section{Discussion}

In the present study, it was found that heparin $(0,0.1,1$ and $5 \mathrm{U} / \mathrm{ml}$ ) dose-dependently inhibited TNF- $\alpha$-induced NF- $\mathrm{NB}$ activation and attenuated the TNF- $\alpha$-induced production of IL-6, IL-8, cyclin D1 and TNF- $\alpha$ in FLSs at mRNA and protein levels. In addition, heparin reduced TNF- $\alpha$-induced cell proliferation.

$\mathrm{NF}-\kappa \mathrm{B}$ signaling is important in the development of inflammation-associated diseases, including RA. NF- $\kappa$ B signaling can be induced by several stimuli, including cytokines, bacteria and oxidative stress (25). Among these stimuli, TNF- $\alpha$ is one of the most important cytokines involved in the development of RA through the activation of several signaling pathways, including $\mathrm{NF}-\kappa \mathrm{B}$ signaling (26). In addition, a previous study reported the presence of a positive feedback loop between NF- $\kappa \mathrm{B}$ and TNF- $\alpha$ (12). Inhibition of the function of TNF- $\alpha$ significantly suppresses the progression of inflammation in RA and has become an important therapeutic approach for the treatment of RA (27).

Heparin is a natural glycosaminoglycan, which is widely used as an anticoagulant $(19,28)$. Aside from its anticoagulant function, it has other biological functions, which remain to be fully elucidated. A previous study suggested a role of heparin in the inhibition of $\mathrm{NF}-\kappa \mathrm{B}$ signaling (19). However, the effects of heparin on the process of inflammation in FLSs and the underlying mechanisms have not been examined. In the present study, the role of heparin in TNF- $\alpha$-induced activation of $\mathrm{NF}-\kappa \mathrm{B}$ was investigated. It was found that heparin attenuated $\mathrm{TNF}-\alpha$-induced $\mathrm{NF}-\kappa \mathrm{B}$ signaling in a dose-dependent manner.

It has been reported that TNF- $\alpha$ can initiate joint destruction and synovial inflammation during the development of RA through the induction of inflammatory cytokines (2). The present study demonstrated that the production of IL-6, IL-8 and cyclin D1 were significantly enhanced in the FLSs treated with TNF- $\alpha$. Heparin significantly attenuated the TNF- $\alpha$-induced production of TNF- $\alpha$, IL-6, IL- 8 and cyclin D1 in the FLSs in a concentration-dependent manner, suggesting its anti-inflammatory role in the RA process. This TNF- $\alpha$-induced production of cytokines was associated with $\mathrm{NF}-\kappa \mathrm{B}$ activation in the FLSs. As heparin inhibited TNF- $\alpha$-induced NF- $\kappa \mathrm{B}$ signaling, it decreased the expression of IL-6, IL-8, cyclin D1 and TNF- $\alpha$, possibly through the inhibition of $\mathrm{NF}-\kappa \mathrm{B}$.

Heparin has been shown to attenuate the proliferation of endothelial cells (29-31). In the present study, it was found that heparin inhibited the proliferation of the FLSs induced by TNF- $\alpha$. In addition, heparin inhibited the expression of cyclin D1, which is an NF- $\mathrm{BB}$ target and acts as a cell cycle regulator involved in cell proliferation (32). These results indicated that cyclin D1 is critical in heparin-induced growth inhibition through the inhibition of NF- $\mathrm{BB}$. The molecular mechanism of heparin-induced $\mathrm{NF}-\kappa \mathrm{B}$ inhibition remains to be elucidated. It was previously reported that this effect may be associated with KLF-5 and growth factors, including EGF and VEGF $(33,34)$. The precise mechanism requires further investigation.

In conclusion, the present study demonstrated that, by suppressing NF- $\kappa$ B activation, heparin inhibited TNF- $\alpha$-induced cell proliferation and the production of cytokines, including IL-6 and IL-8, in FLSs, suggesting that heparin may be beneficial in preventing the progression of RA. Therefore, heparin may be a novel therapeutic approach for the treatment of RA.

\section{Acknowledgements}

This study was supported by the Science and Technology Project of Shenyang (grant no. F12-193-9-41).

\section{References}

1. Huber LC, Distler O, Tarner I, Gay RE, Gay S and Pap T: Synovial fibroblasts: Key players in rheumatoid arthritis. Rheumatology (Oxford) 45: 669-675, 2006.

2. Noss EH and Brenner MB: The role and therapeutic implications of fibroblast-like synoviocytes in inflammation and cartilage erosion in rheumatoid arthritis. Immunol Rev 223: 252-270, 2008.

3. Lafyatis R, Thompson NL, Remmers EF, Flanders KC, Roche NS, Kim SJ, Case JP, Sporn MB, Roberts AB and Wilder RL: Transforming growth factor-beta production by synovial tissues from rheumatoid patients and streptococcal cell wall arthritic rats. Studies on secretion by synovial fibroblast-like cells and immunohistologic localization. J Immunol 143: 1142-1148, 1989.

4. Chu CQ, Field M, Feldmann M and Maini RN: Localization of tumor necrosis factor alpha in synovial tissues and at the cartilage-pannus junction in patients with rheumatoid arthritis. Arthritis Rheum 34: 1125-1132, 1991.

5. Chu CQ, Field M, Allard S, Abney E, Feldmann M and Maini RN: Detection of cytokines at the cartilage/pannus junction in patients with rheumatoid arthritis: Implications for the role of cytokines in cartilage destruction and repair. Br J Rheumatol 31: 653-661, 1992.

6. Zhang HG, Wang Y, Xie JF, Liang X, Liu D, Yang P, Hsu HC, Ray RB and Mountz JD: Regulation of tumor necrosis factor alpha-mediated apoptosis of rheumatoid arthritis synovial fibroblasts by the protein kinase Akt. Arthritis Rheum 44: 1555-1567, 2001. 
7. Alonso-Ruiz A, Pijoan JI, Ansuategui E, Urkaregi A, Calabozo $\mathrm{M}$ and Quintana A: Tumor necrosis factor alpha drugs in rheumatoid arthritis: Systematic review and metaanalysis of efficacy and safety. BMC Musculoskelet Disord 9: 52,2008 .

8. Li G, Zhang Y, Qian Y, Zhang H, Guo S, Sunagawa M, Hisamitsu T and Liu Y: Interleukin-17A promotes rheumatoid arthritis synoviocytes migration and invasion under hypoxia by increasing MMP2 and MMP9 expression through NF- $\mathrm{B} / \mathrm{HIF}-1 \alpha$ pathway. Mol Immunol 53: 227-236, 2013.

9. Criswell LA: Gene discovery in rheumatoid arthritis highlights the CD40/NF-kappaB signaling pathway in disease pathogenesis. Immunol Rev 233: 55-61, 2010.

10. Foxwell B, Browne K, Bondeson J, Clarke C, de Martin R, Brennan $\mathrm{F}$ and Feldmann $\mathrm{M}$ : Efficient adenoviral infection with IkappaB alpha reveals that macrophage tumor necrosis factor alpha production in rheumatoid arthritis is NF-kappaB dependent. Proc Natl Acad Sci USA 95: 8211-8215, 1998.

11. Hwang SY, Kim JY, Kim KW, Park MK, Moon Y, Kim WU and Kim HY: IL-17 induces production of IL-6 and IL-8 in rheumatoid arthritis synovial fibroblasts via NF-kappaB- and PI3-kinase/Akt-dependent pathways. Arthritis Res Ther 6: R120-R128, 2004.

12. Kagoya Y, Yoshimi A, Kataoka K, Nakagawa M, Kumano K, Arai S, Kobayashi H, Saito T, Iwakura Y and Kurokawa M: Positive feedback between NF- $\kappa \mathrm{B}$ and TNF- $\alpha$ promotes leukemia-initiating cell capacity. J Clin Invest 124: 528-542, 2014.

13. Wendling D and Toussirot E: TNF-alpha-targeted therapy in rheumatoid arthritis. Rev Rhum Engl Ed 66: 187-191, 1999.

14. Ding R, Li P, Song D, Zhang X and Bi L: Predictors of response to TNF- $\alpha$ antagonist therapy in Chinese rheumatoid arthritis. Clin Rheumatol 34: 1203-1210, 2015

15. Cavazzana I, Taraborelli M, Fredi M, Tincani A and Franceschini F: Aseptic meningitis occurring during anti-TNF-alpha therapy in rheumatoid arthritis and ankylosing spondylitis. Clin Exp Rheumatol 32: 732-734, 2014.

16. Sakthiswary R and Das S: The effects of TNF $\alpha$ antagonist therapy on bone metabolism in rheumatoid arthritis: A systematic review. Curr Drug Targets 14: 1552-1557, 2013

17. Oudemans-van Straaten HM, Kellum JA and Bellomo R Clinical review: Anticoagulation for continuous renal replacement therapy-heparin or citrate? Crit Care 15: 202, 2011.

18. Ramacciotti E, Clark M, Sadeghi N, Hoppensteadt D, Thethi I, Gomes $\mathrm{M}$ and Fareed J: Review: Contaminants in heparin: Review of the literature, molecular profiling, and clinical implications. Clin Appl Thromb Hemost 17: 126-135, 2011.

19. Li X, Zheng Z, Li X and Ma X: Unfractionated heparin inhibits lipopolysaccharide-induced inflammatory response through blocking p38 MAPK and NF- $\mathrm{BB}$ activation on endothelial cell. Cytokine 60: 114-121, 2012.

20. Lee JH, Lee J, Seo GH, Kim CH and Ahn YS: Heparin inhibits NF-kappaB activation and increases cell death in cerebral endothelial cells after oxygen-glucose deprivation. J Mol Neurosci 32: 145-154, 2007.
21. Livak KJ and Schmittgen TD: Analysis of relative gene expression data using real-time quantitative PCR and the 2(-Delta Delta C(T)) method. Methods 25: 402-408, 2001.

22. Crisostomo PR, Wang Y, Markel TA, Wang M, Lahm T and Meldrum DR: Human mesenchymal stem cells stimulated by TNF-alpha, LPS, or hypoxia produce growth factors by an NF kappa B - but not JNK-dependent mechanism. Am J Physiol Cell Physiol 294: 675-682, 2008.

23. Zheng Y, Ouaaz F, Bruzzo P, Singh V, Gerondakis S and Beg AA: NF-kappa B RelA (p65) is essential for TNF-alpha-induced fas expression but dispensable for both TCR-induced expression and activation-induced cell death. J Immunol 166: 4949-4957, 2001.

24. Schütze S, Wiegmann K, Machleidt T and Krönke M: TNF-induced activation of NF-kappa B. Immunobiology 193: 193-203, 1995

25. McDonald PP, Bald A and Cassatella MA: Activation of the NF-kappaB pathway by inflammatory stimuli in human neutrophils. Blood 89: 3421-3433, 1997.

26. Youn J, Kim HY, Park JH, Hwang SH, Lee SY, Cho CS and Lee SK: Regulation of TNF-alpha-mediated hyperplasia through TNF receptors, TRAFs, and NF-kappaB in synoviocytes obtained from patients with rheumatoid arthritis. Immunol Lett 83: 85-93, 2002.

27. Emery P: Rheumatoid arthritis: International disparities in access to anti-TNF therapy. Nat Rev Rheumatol 7: 197-198, 2011.

28. Ribic C,LimW,Cook D and Crowther M: Low-molecular-weight heparin thromboprophylaxis in medical-surgical critically ill patients: A systematic review. J Crit Care 24: 197-205, 2009.

29. Cao G, Wu JX and Wu QH: Low molecular weight heparin suppresses lymphatic endothelial cell proliferation induced by vascular endothelial growth factor $\mathrm{C}$ in vitro. Chin $\mathrm{Med}$ J (Engl) 122: 1570-1574, 2009.

30. Khorana AA, Sahni A, Altland OD and Francis CW: Heparin inhibition of endothelial cell proliferation and organization is dependent on molecular weight. Arterioscler Thromb Vasc Biol 23: 2110-2115, 2003.

31. Cariou R, Harousseau JL and Tobelem G: Inhibition of human endothelial cell proliferation by heparin and steroids. Cell Biol Int Rep 12: 1037-1047, 1988.

32. Guttridge DC, Albanese C, Reuther JY, Pestell RG and Baldwin AS Jr: NF-kappaB controls cell growth and differentiation through transcriptional regulation of cyclin D1. Mol Cell Biol 19: 5785-5799, 1999.

33. Ettelaie C, Fountain D, Collier ME, Elkeeb AM, Xiao YP and Maraveyas A: Low molecular weight heparin downregulates tissue factor expression and activity by modulating growth factor receptor-mediated induction of nuclear factor- $\kappa \mathrm{B}$. Biochim Biophys Acta 1812: 1591-1600, 2011.

34. Li X, Li X, Zheng Z, Liu Y and Ma X: Unfractionated heparin suppresses lipopolysaccharide-induced monocyte chemoattractant protein-1 expression in human microvascular endothelial cells by blocking Krüppel-like factor 5 and nuclear factor-кB pathway. Immunobiology 219: 778-785, 2014. 